\title{
Rooftop PV and the Renewable Energy Transition; a Review of Driving Forces and Analytical Frameworks
}

\author{
Sam Wilkinson ${ }^{1, *}$, Michele John ${ }^{2}$ and Gregory M. Morrison ${ }^{1}$ (D) \\ 1 Curtin University Sustainability Policy Institute, Curtin University, Bentley, WA 6102, Australia; \\ greg.morrison@curtin.edu.au \\ 2 Sustainable Engineering Group, Curtin University, Bentley, WA 6102, Australia; M.Rosano@curtin.edu.au \\ * Correspondence: sam.wilkinson@curtin.edu.au
}

Citation: Wilkinson, S.; John, M.; Morrison, G.M. Rooftop PV and the Renewable Energy Transition; a Review of Driving Forces and Analytical Frameworks. Sustainability 2021, 13, 5613. https://doi.org/ $10.3390 /$ su13105613

Academic Editor:

Alberto-Jesus Perea-Moreno

Received: 15 March 2021

Accepted: 13 May 2021

Published: 18 May 2021

Publisher's Note: MDPI stays neutral with regard to jurisdictional claims in published maps and institutional affiliations.

Copyright: (c) 2021 by the authors. Licensee MDPI, Basel, Switzerland. This article is an open access article distributed under the terms and conditions of the Creative Commons Attribution (CC BY) license (https:// creativecommons.org/licenses/by/ $4.0 /)$.

\begin{abstract}
Rooftop solar photovoltaics (PV) are accelerating the transition towards low carbon electricity systems in many countries, particularly in Australia. This review paper provides an overview of the (1) technical, (2) economic, (3) socio-political, and (4) regulatory and institutional aspects that should be considered concurrently when navigating the transition towards a rooftop PV-dominated electricity system. We consider the suitability of two prominent long-range transitions theories for understanding the importance and interaction of elements within these four aspects during the transition. The multi-level perspective (MLP) of transitions theory is considered best suited for this task as it addresses fundamental shifts in the socio-technical systems, rather than being weighted towards technological and/or economic solutions. We find that relatively little research has been undertaken where the renewable energy transition is being driven by the uptake of rooftop PV within the distribution network of established islanded electricity systems. These islanded electricity systems will be the first to experience system impacts from high levels of rooftop PV. This review provides further analysis of important gaps in understanding the rooftop-PV-led energy transition and the implications for policy makers in maintaining stable electricity supplies during the transition.
\end{abstract}

Keywords: rooftop PV; variable renewable energy (VER); energy transition; techno-economic paradigm (TEP); multi-level perspective (MLP)

\section{Introduction}

Australia's transition towards an electricity system dominated by renewable energy sources is unfolding faster than many would have expected, particularly given the deep political divide over the need to address climate change in the country. Blakers, et al. [1] reported that Australia is installing wind and solar energy at a rate that is four to five times faster on a per capita basis than is occurring in China, the United States, Japan or the European Union. They further project that, at this rate, Australia would reach 50\% renewable electricity in 2024 and $100 \%$ in 2032. Rooftop photovoltaic (PV) systems are now installed on over a third of homes in some Australian states [2,3]. The rapid uptake of renewable energy is starting to redefine the way electricity systems and their associated markets can operate in Australia and many places around the world [4-8].

Many of the effects of rooftop PV on centrally controlled electricity systems are similar to those from utility scale wind and solar variable renewable energy (VRE) sources, such as their limited dispatchability and inherent variability. There are, however, many effects that are unique to rooftop PV, requiring specific measures and targeted research. Rooftop PV is located within the distribution network, rather than the transmission system [9]. It is produced by parties that have traditionally been electricity customers rather than energy wholesalers [10,11] and their output is neither directly visible to, nor controllable by the integrated system operators (ISOs) $[9,12]$. The very low short-run marginal cost of energy produced by rooftop PV reduces the prices that can be obtained in wholesale energy markets by other generators, causing the merit order effect [13-18]. This effectively reduces 
the profitability of many coal- and gas-fuelled facilities, which then contributes to their early retirement [19]. Whilst this may be viewed as the effective functioning of a market, it has the potential to cause significant system security problems if the traditional thermal generators exit the market quicker than the techno-economic, socio-political, regulatory and institutional challenges can be addressed. Failure to make the timely policy adjustments could result in the need to occasionally disconnect electricity users in some parts of the distribution system to protect the broader electricity system from collapse or to severely limit the numbers and locations of new rooftop PV connections $[19,20]$. Both are politically and socially unpalatable outcomes.

The economic drivers for installing rooftop PV systems are also different to those associated with other generation sources. Domestic and commercial premises installing rooftop PV systems peg their pay-back period against higher retail energy prices rather than the lower wholesale energy prices that utility scale energy projects need to compete with. As a result, there is an acceleration in the uptake of rooftop PV and consequent early retirement of traditional coal and gas generators occurring in some Australian electricity systems [19]. As these traditional generators exit the market, they take with them properties such as inertia, system strength, load following and fault current that they inherently supplied to stabilise the electricity system. Whilst many technical solutions exist to address the loss of these properties from electricity systems, markets do not currently exist that allow for many of these technical solutions to be monetised and therefore enabled. For example, Australian markets do not have mechanisms by which batteries or other distributed energy resources can participate in energy markets or be paid for their network stabilising services. Other mechanisms, such as demand response (DR) programs, virtual power plant (VPP) operators or peer to peer (P2P) trading schemes are also ineligible to bid into electricity markets [21,22]. Managing the transition must therefore consider a number of technical and economic aspects.

Making the market changes to introduce new system-stabilising services will inevitably influence the viability of existing participants and those intending to enter the market. This introduces politically contested spaces that can rely on prior societal acceptance of the need to change if the transition is to be managed in a timely and effective manner $[23,24]$. The scale of this challenge can be amplified with the new role of prosumers, who effectively expand the number of market participants from tens of generators to the millions of generators that will be directly affected by policy shifts. Socio-political factors must also therefore be managed to allow for the rapid uptake of rooftop PV within the distribution system to occur without compromising the security of the electricity system during the transition.

Whilst industry and researchers know that significant electricity system change is occurring and at an accelerating rate, the electricity sector does not have recent experience in dealing with such rapid and significant change [25]. Electricity demand has historically steadily risen, with increasing demand met through slow and well-planned additions of generation and transmission capacity that could be safely implemented within five- to ten-year time horizons [25]. In the case of rooftop PV, much of this change is being exerted upon the incumbent regime by their traditional customers and is requiring substantial infrastructure augmentation to be financed, designed, built and made operational within time periods ranging from months to years [19]. Rooftop PV generation is also being built in an unplanned manner across the distribution system, rather than through the centrally controlled transmission system [26]. This duality combines to represent a fundamental reconfiguration of the relationship between markets, electricity consumption and production patterns and electricity transportation.

With such a fundamental and transformational shift in the provision of energy as an essential service, more knowledge is needed to allow policy makers to understand how the transition can be managed under accelerating timeframes [27] and in a way that guarantees continuity of supply, financial sustainability and supportive prosumer focused business models. Managing the rapid uptake of rooftop PV within the distribution system must 
therefore also address the regulatory and institutional changes that can enable or hinder the transition.

This paper uses a semi-systematic (S-SLR) literature review methodology to identify the key enablers and blockers of a transition to a rooftop PV-dominated electricity system. The primary purpose is to identify, at a high level, the factors that should be considered by policy makers in electricity systems where the transition is being underpinned by rapid adoption of rooftop PV. The primary themes uncovered through the review include the need to consider (1) technical, (2) economic, (3) socio-political, and (4) regulatory and institutional aspects that can either enable or block the transition process. Key factors within each of these aspects are outlined in Section 5 of this paper.

The secondary purpose of this paper is to identify which theoretical frameworks are best used to understand the relationships between the four key aspects identified through the S-SLR and how these relationships inform and assist the transition towards electricity systems dominated by rooftop PV. The objective is to aid policy makers and energy system planners to develop roadmaps of key factors to be considered during the transition and how they relate to each other.

This paper found that the literature uncovered by the search terms either explicitly or implicitly considered transition factors using techno-economic or socio-technical perspectives. In Section 4, the merits of these two long-range analytical frameworks for understanding and guiding policy in the current transition are discussed. Both the techno-economic perspective (TEP) and multi-level perspective (MLP) of socio-technical transitions theory are considered. The TEP has strengths in considering the technical and market related drivers of transitions, whereas the MLP has strengths in integrating the multi-dimensionality and multi-actors involved in spatial and temporal transitions [28]. A key difference between these theories lies in the TEP's underlying philosophy that economic decisions are fundamentally rational [29], whereas socio-technical transition theory makes allowances for decision making processes that can include social, political and other factors that are not necessarily rational [30]. Recommendations for future research into which transition factors should be considered to ensure a stable electricity supply, as brownfield electricity systems shift from traditional thermal coal and gas to systems being dominated by solar PV, are then presented.

In the following section, the methods used to undertake the S-SLR are described. This is followed by an overview of the results obtained from the review in Section 3. Section 4 then investigates frameworks for considering the large amounts of information and multiple aspects relevant to the transition. The aspects identified in the literature that require resolution to enable very high rates of solar PV within electricity systems are then discussed in Section 5. These are discussed as they relate to the technical, economic, socio-political, and the regulatory and institutional aspects. The conclusions drawn from this work and how the aspects are conceptualised within the MLP are then presented in Section 6 , along with recommendations for further research.

\section{Methods}

This paper is grounded in a positivist ontology based on an underlying assumption that a transition is occurring within the electricity sector towards a lower carbon-emitting generation profile. An inductive approach is used [31] within the literature review to identify key themes and issues associated with this energy transition.

A S-SLR process was followed due to its suitability for studying topics that have been conceptualized differently by researchers across diverse disciplines using predominantly qualitative methodologies [32]. As described in Figure 1, this approach combines a systematic literature review (SLR) together with additional references obtained via a snowballing approach using reference and citation tracking of the papers identified by the SLR. This compares with the meta-analysis undertaken within SLRs, which are best employed to quantitatively analyse comparisons of research paper findings that have each used similar methodologies [32,33]. Sovacool, et al. [34] also reported that SLRs are suited to studies 
with relatively narrow research questions rather than multidimensional problems. The S-SLR process, by contrast is useful for obtaining an overview of issues and analytical frameworks used to interpret research problems [32].


Figure 1. Semi-systematic literature review methodology used in this paper.

As described by Figure 1, the review was undertaken in three phases. The first phase followed a SLR process using the search terms contained in Table 1. These terms were formulated to answer the central research question of: what factors enable and/or hinder the uptake of rooftop PV within brown field electricity systems and which analytical frameworks have been used? The search criteria focused on identifying literature review papers as these can assist in rapidly identifying key themes, research approaches and gaps in a scientific field [35], which was a key aim of this exploratory research. Results were limited to peer-reviewed literature published in the past five years. Key themes identified through the SLR were coded into NVIVO 12 social science software in accordance with themes that emerged through their review.

Table 1. Search terms used for the SLR, the number of returned results and the number of papers consequently selected for further review and synthesis.

\begin{tabular}{|c|c|c|c|}
\hline Database & Search Terms & Results * & $\begin{array}{l}\text { Selected for } \\
\text { Further Review }\end{array}$ \\
\hline Scopus & 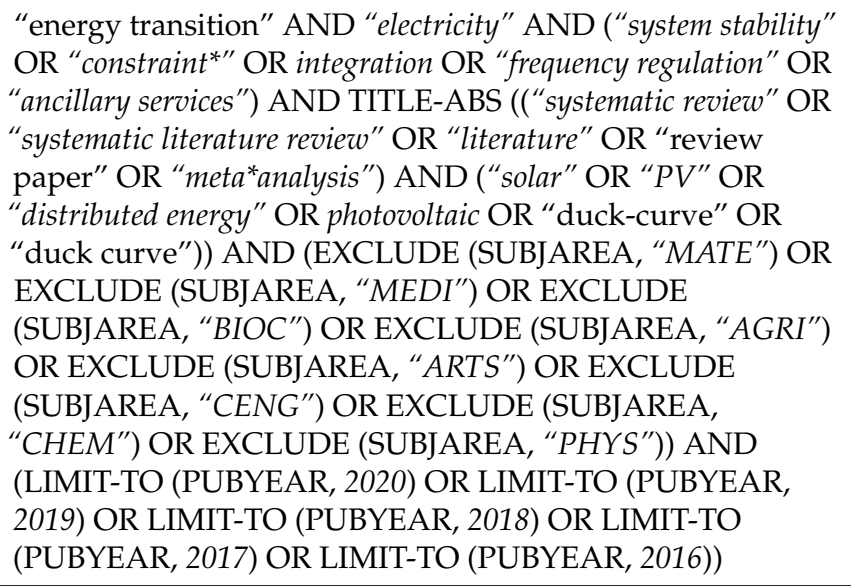 & 88 & 50 \\
\hline Scopus & $\begin{array}{l}\text { "energy transition" AND “electricity" AND ("system } \\
\text { stability" OR “constraint*" OR integration OR “frequency } \\
\text { regulation" OR "ancillary services") AND TITLE-ABS } \\
\text { (("systematic review" OR “systematic literature review" OR } \\
\text { "literature" OR "meta*analysis") AND ("solar" OR “PV" OR } \\
\text { "distributed energy" OR photovoltaic) AND (enable* OR } \\
\text { allow OR assist OR facilitate OR encourage OR hinder OR } \\
\text { discourage OR block* OR obstruct OR delay OR impede OR } \\
\text { deter)) AND (LIMIT-TO (PUBYEAR,2021) OR LIMIT-TO } \\
\text { (PUBYEAR,2020) OR LIMIT-TO (PUBYEAR,2019) OR } \\
\text { LIMIT-TO (PUBYEAR,2018) OR LIMIT-TO (PUBYEAR,2017) } \\
\text { OR LIMIT-TO (PUBYEAR,2016)) }\end{array}$ & $30(11)$ & 8 \\
\hline
\end{tabular}


Table 1. Cont.

\begin{tabular}{|c|c|c|c|}
\hline Database & Search Terms & Results * & $\begin{array}{c}\text { Selected for } \\
\text { Further Review }\end{array}$ \\
\hline \multirow[t]{3}{*}{ Web of Science } & $\begin{array}{l}\text { ALL = ("energy transition" AND “electricity" AND } \\
\text { ("system stability" OR "constraint" OR integration OR } \\
\text { "frequency regulation" OR "ancillary services")) AND } \\
\text { AB = (("systematic review" OR "systematic literature } \\
\text { review" OR "review paper" OR “literature" OR } \\
\text { "meta*analysis") AND ("solar" OR "PV" OR “distributed } \\
\text { energy" OR photovoltaic)) }\end{array}$ & $5(1)$ & 1 \\
\hline & Papers excluded after detailed review & & 8 \\
\hline & Total & & 51 \\
\hline
\end{tabular}

${ }^{*}$ Unique results not uncovered in preceding search are listed in brackets.

References were limited to those relevant to the adoption of renewable energy in brownfield electricity systems and excluded literature pertaining to the adoption of these technologies in developing countries that did not have pre-established centralised energy systems. As noted by Sareen and Kale [36], the issues facing developing and developed countries can be markedly different from each other.

After analysis of the literature uncovered by the SLR, broader literature was then identified via a snowballing technique using reference and citation tracking of the SLR papers. This approach was used to further interrogate the specific enablers, blockers and analytical frameworks identified through the SLR and to gain additional context on issues uncovered through the initial literature search. Results from phases one and two were then integrated for the final report write-up.

\section{Overview of SLR Papers and Their Theoretical Framing of the Energy Transition}

Of the 51 papers analysed via the SLR, only five were dedicated literature review papers specific to the uptake of rooftop PV. This is not surprising given that rooftop PV is a relatively new and developing area and is consistent with the literature reviews within the remaining papers. These five papers analysed the energy transition by focusing on sociopolitical factors [37], economic factors [38] or combined socio-technical issues including, technical, economic, social, political, regulatory and institutional factors [39-41]. A further 22 of the papers were dedicated literature reviews, however these were generic to the energy transition, rather than being specific to rooftop PV adoption. The remaining papers contained literature reviews that were generic to various aspects of the energy transition.

The review of all papers uncovered by the SLR found that managing the energy transition has been studied through the separate consideration of technical issues, economic/financial factors, socio-political issues and/or regulatory and institutional issues. These factors are defined in Table 2, along with an indication of the number of papers that included those aspects within their analysis. A complete breakdown of which SLR papers considered these aspects is presented in Appendix A.

The literature also, either implicitly or explicitly, presented analyses within either socio-technical or techno-economic theoretical framings. These frameworks emphasise the relative importance that the aspects identified within Table 2 provide in terms of influencing the energy transition. Section 4 details the strengths and weaknesses of these two theoretical frameworks. A summary of how the literature considers the four factors in Table 2 that enable and/or hinder the uptake of very high levels of rooftop PV is then summarised in Section 5 . 
Table 2. Categorisation of aspects that influence the uptake of VRE and rooftop PV based on specific elements of the socio-technical regime. The third column shows the number of papers uncovered in the SLR that addressed the respective aspects (note that papers typically addressed more than one aspect).

\begin{tabular}{clc}
\hline Aspect & \multicolumn{1}{c}{ Characteristic } & No. of Papers \\
\hline Technical & $\begin{array}{l}\text { Studies that investigate the operational characteristics of the } \\
\text { physical electricity production, conversion, distribution, } \\
\text { transmission and control infrastructures and systems. }\end{array}$ & 30 \\
\hline Economic & $\begin{array}{l}\text { Studies that consider the financial drivers and investment } \\
\text { impediments associated with the electricity system }\end{array}$ & 31 \\
\hline Socio-political & $\begin{array}{l}\text { Consideration of the politics of energy together with its } \\
\text { intersection with electricity users and prosumers and their } \\
\text { adoption of new technologies and business models. It includes } \\
\text { ethical issues such as social justice. }\end{array}$ \\
\hline Regulatory and Institutional & $\begin{array}{l}\text { Primarily related to the policy and regulatory settings and the } \\
\text { ability of institutions to adapt to the changes related to the } \\
\text { niche innovations and business models. }\end{array}$ \\
\hline
\end{tabular}

Overall, articles were sourced from 25 different journals, reflecting the breadth of journal disciplines that are providing coverage of the renewable energy transition and the divergent factors that are relevant to the energy transition. The foci of the journals were also broad, with the majority taking an extended triple bottom line sustainability focus. Journals included those with a focus on the economic, policy, social sciences or technical/applied aspects. Of the 52 articles selected for inclusion in the review, 10 were sourced from Renewable and Sustainable Energy Reviews, 7 from Applied Energy (7) and 5 from Energy Research $\mathcal{E}$ Social Science (5) (Figure 2). A further 17 articles were sourced from 17 different journals, with the balance coming from journals that supplied 2-3 articles.

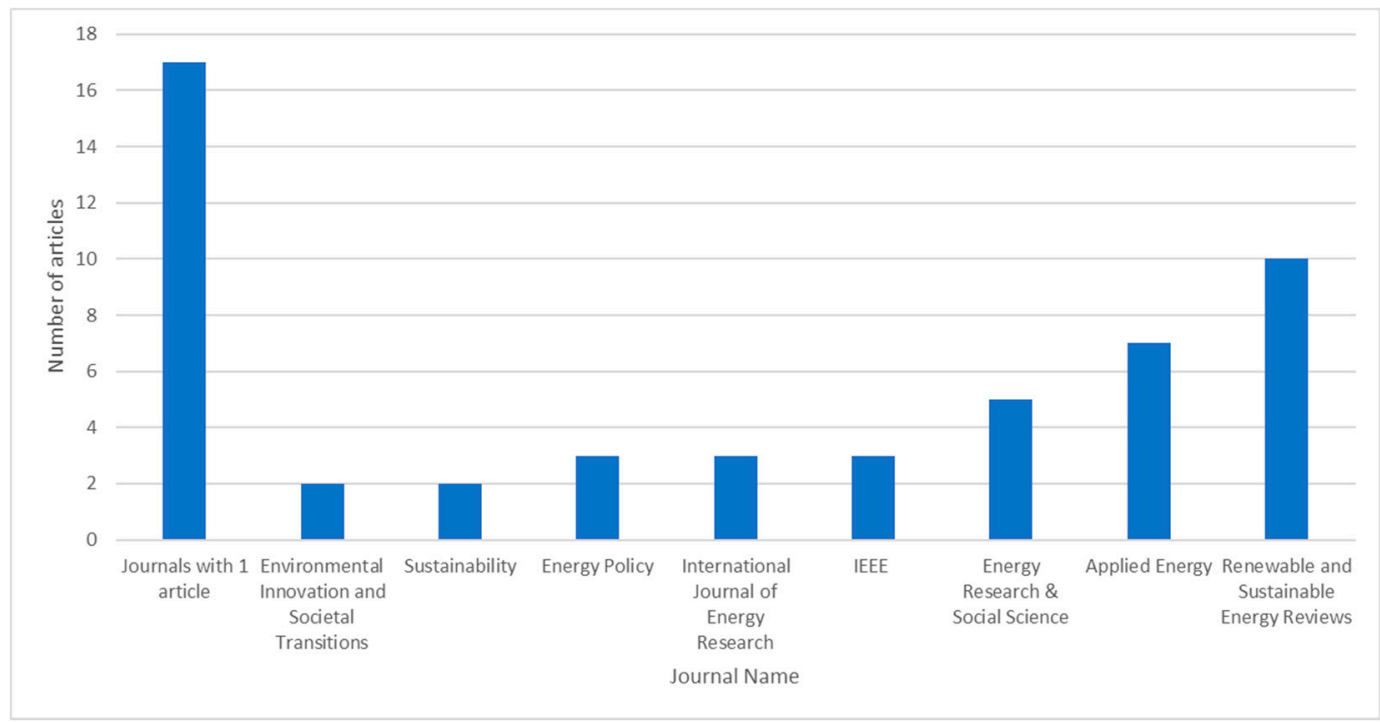

Figure 2. Journals from which SLR articles were sourced.

\section{Analytical Frameworks for Understanding Renewable Energy Transitions}

This section considers two prominent long-range theories used to consider energy transitions - the techno-economic paradigm (TEP) and the multi-level perspective (MLP) of socio-technical transitions. Understanding the energy transition requires the coordination of multiple factors beyond technical and economic aspects [42,43]. This can be aided by using theoretical frameworks, which are heuristic approaches that assist researchers to order and make sense of large amounts of information [44]. The adoption of frameworks 
for ordering information is critical in understanding and managing the energy transition, since any changes to its production and delivery will influence the institutions, political spheres, and normative behaviours of those using it.

Sovacool and Hess [44], considered 96 different theories and conceptual approaches that could be used for explaining the adoption, use, acceptance, diffusion or rejection of new technology. The adoption and integration of rooftop PV into electricity systems can be considered a new technology in this context. They found that the major theories integrate multiple theoretical perspectives to make sense of the differing factors that influence the diffusion or rejection of innovations such as solar PV adoption. The MLP was the most popular theory amongst their interview respondents and is considered to be the dominant framework used to assess transitions within the socio-technical transitions literature [28]. By comparison, the TEP is a dominant framework that gives pre-eminence to technological and economic factors as drivers for a transition, which were the most regularly researched aspects uncovered in this review.

\subsection{Techno-Economic Paradigm (TEP)}

The TEP is based on Schumpeter's principles of creative destruction, where new technologies, led by entrepreneurs enter the market and catalyse the shifts in supportive technologies [45]. Shifts that occur under a TEP require the institutions, rules and social norms that have locked in existing technologies to make way for clusters of new technologies to diffuse in a manner that ultimately shifts the economy [46]. The concept of clusters of technologies that are required to support each other was originally introduced by Freeman [47]. The waves of transition described under the TEP occur over several decades and were characterised as relating to five separate waves (these waves started with the industrial revolution (starting 1771), shifting to steam and railways (starting 1829), the age of steel and electricity (starting 1875), the age of the automobile, oil and mass production (starting 1908) and then the age of information technology and telecommunications (starting 1971) [46]). Whilst Schumpeter saw the institutions, technologies and social organisations as external to the economy, Perez [46] viewed these as internal to the waves of transitions that occur under TEPs.

The successful diffusion of an innovation is fundamentally underpinned by complementary technological innovations that are cost competitive and have a market that is willing to adopt and diffuse them, ultimately resulting in modifications to the socioinstitutional structures [46]. Use of the TEP to order information relevant to the energy transition would therefore focus on how to foster supporting technologies and associated markets, whilst acknowledging the need to modify supporting institutions.

Technological aspects were the focus of 30 of the 52 papers identified during the SLR component of this review, whilst economic and financial aspects of renewable energy uptake was considered relevant within 31 of the papers. These were the most consistently researched aspects of transitions towards higher rates of renewables within electricity systems, which reflects the weighting towards these factors within the TEP's theoretical framing.

\subsection{Multi-Level Perspective (MLP)}

The MLP is derived from evolutionary economics, institutional theory and the sociology of innovation [28,29]. It has often assessed the feasibility of low-carbon transition pathways through analysis of historical niche, regime and landscape developments. Analysing historical transitions can inform our understanding of the enablers and blockers to currently unfolding transitions and can provide insights into potential future transitions pathways [29].

The premise of the MLP is based on sustainability transitions being influenced by dynamics within and between the heuristic levels of the niche, landscape and regime [48]. In the context of the MLP, the niche is where technological innovations can grow and emerge [49-51]. The ability of niches to expand into the regime is influenced by the forces 
at play within both the socio-technical regime and the overarching landscape. The sociotechnical regime is the structure that accounts for the dynamic stability of the socio-technical system and is made up of the rules, actors and behavioural norms of the socio-technical system [52]. This can include separate but intertwined policy, science, technological, user and market and socio-cultural regimes [52,53]. The relationships between these socio-technical regime elements can be self-reinforcing, which can lock-in existing technologies and block the breakthrough and diffusion of emerging niche innovations unless there is an internal regime requirement for the innovation or there are external landscape forces that force a reorganisation of the socio-technical regime, thereby creating the space for the innovation $[54,55]$. Examples of landscape forces include climate change, war, global pandemics or recession, which drive social and political changes that encourage a reorganisation of the socio-technical regime to adopt the innovation. The actors and groups within the heuristic levels interact in accordance with cognitive, normative and regulative rules [48] and, in so doing, they influence the transition pathways, which can unfold over a number of decades.

\subsection{Strengths and Weaknesses of the MLP and TEP}

Both the MLP and TEP are focused on change processes that occur over decades. Rooftop PV was initially introduced in the late 1970's [56] and as such, its study using these frameworks can be considered appropriate. The system building role of users in breaking down the existing regime during the energy transition has been proposed by Schot, et al. [57]. However, these changes are focused on multi-decadal transition dynamics and do not pay sufficient attention to the micro dynamics and agency of the users associated with innovations at the local scale [58]. In situations where niche innovations such as rooftop PV are breaking through into a phase of wide dispersion within the sociotechnical regime, further research should be undertaken into how long-range theories can be augmented by shorter-range theories with finer granularity.

The strength of the MLP is in its recognition of the multi-dimensionality and multiactors involved in spatial and temporal transitions [28]. This is particularly relevant for sustainability transitions, which require fundamental shifts in the socio-technical systems, rather than just technological fixes [28]. However, the MLP has received criticism for how it addresses geographical space [59-62], the boundaries between niche, regime and landscape [63] and for its ambiguous methodology, weighted towards bottom-up change models [44,52].

An important assumption of techno-economic transitions is that economic decisions are fundamentally rational [29], which contrasts with socio-technical transition theory, which makes allowances for multifaceted decision making processes that can include social, political and other factors that are not necessarily rational [30]. The TEP has been criticised for undervaluing the roles played by civil society, users, scientists, engineers, media and other social groups, whilst placing most attention on financial institutions and governments in creating the space for turning points or shifts to occur [64]. The need to consider these additional factors is supported by this paper's SLR, which identified the importance of users, scientists, and civil society [40,65-67] in the transition to VRE. The TEP has also been criticised for its lack of emphasis on political contexts and broad landscape factors (such as wars and climate change), the over emphasis on the role of the state (assuming that transitions emerge at the level of the state) and that it doesn't provide details on what happens to the existing paradigm of technologies [64]. Each of these factors have been identified through the full S-SLR as being important in a VRE transition (refer to Table 3 for a weighting of how each of the MLP and TEP considers the factors that should be considered during the transition). 
Table 3. Weighting of the MLP and TEP strengths in integrating the key aspects identified in this literature review.

\begin{tabular}{ccc}
\hline Aspects & Multi-Level Perspective & Techno Economic Paradigm \\
\hline Technical & High & High \\
\hline Economic and financial & Medium & High \\
\hline Socio-political & High & Medium \\
\hline Regulatory and Institutional & High & Medium \\
\hline
\end{tabular}

To summarise, key aspects that should be considered when making sense of a transition towards high rates of rooftop PV within an energy system include: technological aspects; economics and markets; users and associated behaviours; global shifts together with political, regulatory and institutional settings; and the interaction between all these aspects. The two long range theories considered above, can frame these multi-dimensional factors in the unfolding energy transition. However, the TEP's emphasis on rational decision making associated with economics and technology decisions make it a less well nuanced framework than the MLP of socio-technical transitions theory. The MLP is well suited for use by researchers and policy makers seeking to understand the multi-faceted dynamics within an energy transition. The MLP may need augmenting by those researchers and policy makers seeking to understand rapid change processes driven by emerging niche technologies such as rooftop PV that can operate at the scale of sub-national electricity systems or within those systems.

\section{Challenges Associated with Transitioning to Very High Rates of Rooftop PV within Electricity Systems}

Very high rates of rooftop PV within electricity systems impose a series of challenges to the operational reliability of electricity systems. Table 4 presents the broad range of challenges, which have been grouped as technical, economic, socio-political and regulatory and institutional. Managing the transition will require an understanding of each of these challenges and their interrelationships within the socio-technical regime.

Table 4. Issues associated with high rates of rooftop PV in electricity systems.

\begin{tabular}{|c|c|c|}
\hline Issue Type & Challenge & Cause \\
\hline \multirow{4}{*}{ Technical } & $\begin{array}{l}\text { Mismatch between system load } \\
\text { and generation capabilities }\end{array}$ & $\begin{array}{l}\text { More thermal generators (e.g., coal and gas) will fall below their } \\
\text { minimum generation level during midday hours, causing them to } \\
\text { either cycle on and off }{ }^{1} \text { or to pay other generators not to run. This may } \\
\text { result in generation being unavailable to support afternoon ramping } \\
\text { and/or evening peak loads whilst also removing the additional system } \\
\text { support services that they inherently supply (as summarised in the } \\
\text { remainder sub-section of this table). }\end{array}$ \\
\hline & $\begin{array}{l}\text { Lack of visibility and control of } \\
\text { significant a portion of generation }\end{array}$ & $\begin{array}{l}\text { As for the above challenge, a significant portion of midday demand } \\
\text { will be supplied via inverter-connected rooftop PV systems that are } \\
\text { neither visible nor controllable by the ISO. The ISO is only able to } \\
\text { dispatch utility scale generators (those greater than } 10 \mathrm{MW} \text { ) for } \\
\text { maintaining system security. }\end{array}$ \\
\hline & Reduced system inertia & $\begin{array}{l}\text { Traditional thermal generators have high spinning inertia, which can } \\
\text { resist the rate of change in frequency }[68,69] \text {. Exit of these generators } \\
\text { results in a reduction in inertia, which makes systems more vulnerable } \\
\text { to frequency variation. }\end{array}$ \\
\hline & More rapid frequency fluctuations & $\begin{array}{l}\text { Uncontrolled VRE without storage respond almost instantly to changes } \\
\text { in cloud cover (PV) and wind speed (wind turbines). As a result, } \\
\text { inter-interval generation can vary significantly pending changing } \\
\text { weather conditions, requiring additional frequency regulation } \\
\text { services [69]. }\end{array}$ \\
\hline
\end{tabular}


Table 4. Cont.

\begin{tabular}{|c|c|c|}
\hline Issue Type & Challenge & Cause \\
\hline & Voltage regulation & $\begin{array}{l}\text { As the minimum system load drops, there is expected to be insufficient } \\
\text { synchronous generation on-line to absorb the elevated reactive power } \\
\text { that results from rooftop PV systems exporting into the distribution } \\
\text { system [19] in some electricity systems. }\end{array}$ \\
\hline & System strength ${ }^{2}$ & $\begin{array}{l}\text { Synchronous generators inherently supply system strength, which } \\
\text { contributes to system security and is needed most at the centre of the } \\
\text { system [70]. Inverter-connected VRE's produce very low levels of } \\
\text { system strength and, in the case of rooftop PV are located on the } \\
\text { distribution network close to demand centres. Conversely, the existing } \\
\text { thermal generators, around which the existing system has been } \\
\text { designed, are located further out on the transmission network. }\end{array}$ \\
\hline & Ramp rate & $\begin{array}{l}\text { The new system load profile characterised by the duck curve with low } \\
\text { midday demand and high evening peak requires substantially more } \\
\text { ramping than the historically flatter load profile. }\end{array}$ \\
\hline \multirow{4}{*}{ Economic } & Merit order effect & $\begin{array}{l}\text { Near zero short run marginal cost renewables are reducing the clearing } \\
\text { prices in energy markets, which is pricing base-load generators out of } \\
\text { the market [13-18] and can exacerbate the technical issues identified } \\
\text { above. }\end{array}$ \\
\hline & Missing money & $\begin{array}{l}\text { Renewable energy sources reduce the value and length of peak energy } \\
\text { price periods that, in turn, reduces the financial viability of mid-merit } \\
\text { and peaking plants }[6,71-74] \text { and can exacerbate the technical issues } \\
\text { identified above. }\end{array}$ \\
\hline & $\begin{array}{l}\text { Markets do not exist for new } \\
\text { requirements }\end{array}$ & $\begin{array}{l}\text { Many wholesale energy markets do not have rules that would allow } \\
\text { the following to monetise their services that could address many of the } \\
\text { technical issues identified above }[4,75,76] \text { : } \\
\text { Chemical energy storage batteries; } \\
\text { Distributed demand response programs (including via virtual power } \\
\text { plants (VPPs) and peer to peer (P2P) energy trading schemes); } \\
\text { Micro-grids. }\end{array}$ \\
\hline & Value of electricity & $\begin{array}{l}\text { Electricity has become a societal right and politically must be available } \\
\text { to all at a minimal cost [15]. Low-cost electricity reduces the potential } \\
\text { effectiveness of tariffs that could change behaviours and therefore } \\
\text { flatten the system load. }\end{array}$ \\
\hline \multirow{4}{*}{ Socio-political } & $\begin{array}{l}\text { Changing societal } \\
\text { roles/relationships with energy }\end{array}$ & $\begin{array}{l}\text { Households have traditionally been electricity customers; however, } \\
\text { they are now suppliers of energy to the system and will increasingly be } \\
\text { called up to help manage and stabilise the electricity system in a role as } \\
\text { prosumer [77]. }\end{array}$ \\
\hline & Energy justice & $\begin{array}{l}\text { Grid defection by those able to afford rooftop PV and/or batteries is } \\
\text { driving up costs for those that remain connected to the grid. [78-81]. }\end{array}$ \\
\hline & Public versus private & $\begin{array}{l}\text { With electricity becoming a societal right, renewed arguments arise } \\
\text { over the role of government provision requirements [15]. In many } \\
\text { systems, the government owns a significant portion of the existing } \\
\text { generation and/or transmission and distribution system. Any policy } \\
\text { changes allowing further development of renewable energy can } \\
\text { negatively impact government assets and revenues, which can lead to } \\
\text { inefficient decisions. }\end{array}$ \\
\hline & Balancing divergent interests & $\begin{array}{l}\text { Political decisions have been shown to be major determinants of the } \\
\text { form that energy transitions take }[36,82,83] \text {. }\end{array}$ \\
\hline \multirow[b]{2}{*}{$\begin{array}{l}\text { Regulatory and } \\
\text { Institutional }\end{array}$} & Clarity of purpose & $\begin{array}{l}\text { Lack of climate and energy targets, resulting from lack of agreement on } \\
\text { the realities of climate change, creates investment and policy uncertainty. }\end{array}$ \\
\hline & Speed of change & $\begin{array}{l}\text { Traditional generation and network planning and implementation } \\
\text { cycle of } 5-10 \text { years is too long to handle urgent challenges created by } \\
\text { high level PV penetration. }\end{array}$ \\
\hline
\end{tabular}


Table 4. Cont.

\begin{tabular}{ll}
\hline Issue Type & \multicolumn{1}{c}{ Challenge } \\
\hline $\begin{array}{l}\text { Strong network problems and } \\
\text { path-dependencies }\end{array}$ & $\begin{array}{l}\text { Celf-reinforcing constructs exist where firms have critical exchange } \\
\text { partners with whom they prefer to conduct business, that are closed to } \\
\text { outsiders. Their effective regime of suppliers, customers, funding } \\
\text { bodies, regulatory groups, trade associations and the general public } \\
\text { can create a lock-in mechanism that reduces the ability of organisations } \\
\text { to make rapid change [84]. }\end{array}$ \\
\hline Human resources & $\begin{array}{l}\text { As change is occurring at such a rapid pace, there is often not enough } \\
\text { appropriately skilled staff to resolve emergent issues [39]. }\end{array}$ \\
\hline
\end{tabular}

\footnotetext{
${ }^{1}$ Cold or warm re-starts cost in the order of AUD 350/MW or AUD 120/MW, respectively, for coal units. With units ranging in size from $120 \mathrm{MW}$ to $330 \mathrm{MW}$, these restarts can cost AUD 14,000 to AUD 40,000 per warm restart and AUD 42,000 to AUD 115,000 per cold restart depending on the individual unit sizes. [85] These costs do not include the increased maintenance costs associated with cycling these units. 2 System strength is the available fault current at a specified location in the power system, where higher fault current indicates higher system strength [71]. It represents the ability of the power system to both remain stable under normal conditions and return to steady state conditions following a disturbance [19].
}

The largest body of available literature was focused on the technical integration of rooftop PV systems (30 of 51 articles) and the economic problems and/or opportunities that this presented to the electricity system and its users (31 articles). The following sections provide additional information on the technical, economic, socio-political and regulatory and institutional challenges posed by high levels of rooftop PV specifically and VRE generally.

\subsection{Technical Aspects}

In traditional centralised energy systems, electricity is transmitted across the network in an alternating current that changes frequency at a rate of 50 or 60 hertz (dependent on the jurisdiction). The frequency is used as a measure of the system's balance and must be maintained within a close band of approximately plus or minus 0.5 hertz to avoid system collapse. The system's frequency will drop when a generator trips off, or customers turn on equipment that draws power. The centralised integrated system operator (ISO) responds in these situations by dispatching generators up or down to bring the frequency back to a safe level and thereby ensure that the instantaneous supply and demand for electricity is balanced. To do so, the ISO has historically had visibility over the operating parameters of all generators in the power system and the capacity to dispatch them up or down in response to system requirements.

Rooftop PV, however, is not visible to ISOs and is also not controllable or dispatchable by them $[86,87]$. This has not been a problem in power systems where rooftop PV contributes relatively small amounts to the electricity system. This creates several problems for ISOs where a significant proportion of instantaneous energy demand is coming from self-generated rooftop PV systems during some trading intervals. It can push the midday energy demand below the minimum operating levels of the larger coal and gas generators, forcing some of them to switch off, leaving ISOs with fewer options to dispatch and control for frequency variations. Some generators can cope with this fluctuation, such as gas turbines, which can cycle on and off over the course of the day, but for large steam-driven generators, such as coal and open cycle gas turbines, cycling on and off within a day may not be a viable option. These generators have been required to meet the afternoon and evening peak demand periods and therefore have been required to stay on during the midday low demand periods to avoid cycling costs. To do so, they have increasingly been forced to bid negative prices into the energy market, effectively paying to displace low priced utility scale wind and solar facilities to discourage them from producing. The larger steam generators have also introduced high levels of inertia into the power system, which has further slowed the rate of change in frequency due to changes in load and/or generation. Displacement of these generators by rooftop PV from the energy system reduces system inertia. 
Rooftop PV can fluctuate rapidly in response to cloud movements and the rising and setting sun, giving rise to the term variable renewable energy (VRE) source. Whilst the rising and falling of the sun is entirely predictable, it often occurs close to the system's peak demand periods, which accentuates the concurrent steep ramp rate and requiring market participants to rapidly supply energy at those times. This becomes more challenging when rooftop PV has displaced these generators from the market during the middle of the day. The effects of cloud movements can largely be predicted and controlled with accurate weather forecasting $[74,88]$. It does, however, introduce additional variability that needs to be increasingly managed by ISOs and, if done poorly, can result in market inefficiencies $[74,88]$.

As the minimum system load drops with additional rooftop PV, there can be insufficient synchronous generation on-line to absorb the elevated reactive power and voltage levels that result from rooftop PV systems exporting into the distribution system [19]. The increasing proportion of inverter-connected devices together with the removal of traditional thermal generators reduces fault current and therefore system strength [89]. System strength is the available fault current at a specified location in the power system, where higher fault current indicates higher system strength [71]. It represents the ability of the power system to both remain stable under normal conditions and to return to a steady state condition following a disturbance [19]. Inverter-connected energy sources, such as rooftop PV and utility scale wind and solar facilities effectively supply no fault current.

ISOs currently lack control systems that can deal with the shift from tens of generators that were located on the transmission system towards one that has a very large number of small inverter-connected rooftop PV systems generating significant portions of the energy from within the distribution system. This will require improved coordination between the distribution system and transmission system operation [26] and the development of automated control mechanisms [90].

ISOs also lack technologies, such as improved inverter and metering technologies, that can allow them to control the rooftop PV systems located across the distribution system, [91,92]. The absence of these devices has also been identified as an issue that impacts the ability to implement time of use tariffs, or to be externally controlled by third parties via demand response (we have adopted the definition for demand response as used by [93]: "Changes in electric usage by end-use customers from their normal consumption patterns in response to changes in the price of electricity over time, or to incentive payments designed to induce lower electricity use at times of high wholesale market prices or when system reliability is jeopardized") programs or to participate in distributed energy markets such as VPPs and P2P schemes [94]. These programs and markets have been proposed as mechanisms that could incentivise load shifting and reduce ramp-rate requirements [14,95]. These programs and markets may also be used to address short-term energy supply and demand imbalances and to meet requirements for additional frequency response $[7,76]$.

Much of the research into technical impacts and solutions to high VRE and rooftop PV impacts on power systems is focused on electricity systems that have interconnections to neighbouring power systems or in very small standalone micro-grids. Limited research has been undertaken on electricity systems servicing several million customers that have very high rates of VRE, including rooftop PV and that are islanded from any neighbouring electricity system. These islanded systems are likely to demonstrate the impacts of rooftop PV sooner than larger systems that can import support from neighbouring electricity systems and therefore islanded systems warrant further research.

\subsection{Economic Aspects}

The costs of rooftop PV and other VRE sources have dropped dramatically over the past decade, with the International Renewable Energy Agency reporting that $80 \%$ of PV and wind projects commissioned from 2020 will produce electricity cheaper than fossil fuel alternatives [96]. Similarly, the cost of lithium ion battery packs has fallen $87 \%$ between 2010 and 2019 [97], with rooftop PV prices falling 79\% in the same period [98]. At the 
same time, electricity prices purchased from the grid have typically been increasing, which further incentivises customers to invest in self-generation and the accelerated uptake of associated batteries. The International Energy Agency projects that $80 \%$ of the growth in energy demand will be met by solar PV over the next decade [99]. They also note that PV is now cheaper than both gas and coal generation in most countries and that it is producing electricity at the lowest costs ever recorded [99]. These landscape-level price changes can be expected to accelerate rooftop PV uptake and intensify the need to address the associated impacts.

Rooftop PV and utility scale VRE sources have been shown to suppress the clearing price in energy markets, reducing the profitability of traditional base-load generation in many energy markets around the world [13-18,100]. This phenomenon is referred to as the merit order effect (MOE). In addition, these renewable energy sources reduce the value and length of peak energy price periods causing the "missing money problem" which reduces the financial viability of mid-merit and peaking plants [6,72-75]. Whilst this may be viewed as the effective functioning of a market, it has the potential to cause significant system security problems if the traditional thermal generators exit the market quicker than the techno-economic, socio-political, regulatory and institutional aspects can be addressed.

Whilst many technical solutions exist to address the challenges introduced to system operation by rooftop PV, energy markets do not currently exist that allow for many of these technical solutions to be monetised. For example, many markets do not have a mechanism by which distributed energy resources can participate in demand response programs, nor for aggregators, VPP operators or P2P trading schemes to bid into a market $[21,22]$. Similarly, batteries are excluded from participating in many energy markets. Market rules in some jurisdictions were developed to only allow generators to provide system support services, thereby excluding the use of batteries and other non-synchronous technologies $[101,102]$. This is a legacy issue reflecting the times in which the rules were originally written, but updating these rules introduces political and vested interest debates that can take many years to resolve.

Tariff reforms aimed at flattening the load curve can be an effective mechanism for reducing evening peak ramping requirements and raising the mid-day minimum system load $[14,103,104]$. This can be helpful to slow the speed at which traditional coal and gas generators need to exit the market due to a miss-match between their operating characteristics and the new system load. This provides policy makers with additional time to address the technical, economic, regulatory, institutional and socio-political factors required to maintain a stable electricity supply with increasing rates of rooftop PV. However, with electricity now considered an essential service and societal right, politicians must ensure that it is available to all at a minimal cost [15]. By supplying electricity at a very low cost, the potential effectiveness of tariffs as a mechanism for changing behaviours that flatten system loads is diminished.

Managing the transition will therefore require market mechanisms that can value potential solutions to the challenges posed by introducing new technologies and removing/reducing historical and legacy dominant technologies. Doing so requires an understanding of the interplay between the socio-political, techno-economic, technical, regulatory and institutional mechanisms that have developed and locked in the legacy regime.

\subsection{Socio-Political Aspects}

Nearly half of the references within the SLR identified the importance of user acceptance of renewable energy technologies and/or enabling business models for a successful transition. Socio-political acceptance relates to community acceptance at the broadest level [24] and can be reflected in the decisions that politicians make within democratic countries. Each of the technical and economic challenges identified in the preceding section will need to be addressed to allow for a successful transition, which will be dependent on prior political and social acceptance $[23,24]$ to enable their introduction. This section 
presents the S-SLR findings related to how political and social acceptance are high-level enablers and blockers to the adoption of significant rates of rooftop PV.

Low levels of rooftop PV uptake can be facilitated without many regulatory changes, however, as penetration levels become significant, as is occurring in Australia, political support to enable the required policy and regulatory changes becomes increasingly critical. Hess and Lee [8] argued that there are often convoluted political policy logics in play, which has allowed conflicting policy proposals to be argued for by both incumbent and emergent technologies. This has the effect of slowing the transition process.

Policies to support technologies such as rooftop PV, batteries and electric vehicles typically lag behind both the technological advancements and rates of implementation currently experienced with these technologies [40]. This points to the importance of political support for policy development, a factor supported by research into the adoption of distributed energy resources in the United States [83], UK [78], as well as PV in India [36], and Africa [105]. Huang [84] found that policy support in China was most effective when it occurred consistently across each level of government.

Political decisions have been shown to be major determinants of the structural form that energy transitions take on $[36,83,84]$. Sareen and Kale [36] noted that many political decisions are made to promote certain renewable technologies without consideration of their relationship to the broader electricity system and other renewable energy sources. Lenhart, Chan, Forsberg, Grimley and Wilson [83] showed that political relationships were the greatest determinant of the amount and type of renewable energy adopted within municipal utilities in the United States.

Jurisdictions affected by rapid adoption and penetration rates of rooftop PV in their electricity systems must therefore identify and implement mechanisms for empowering politicians to lead the transition processes. Democratically elected politicians must be empowered by their voters and media to make the changes that can allow for a reconfiguration of the socio-technical regime. This could be through the setting of carbon reduction targets but must focus on allowing implementation of the enabling technologies, such as batteries, control systems and infrastructure, together with supporting markets and tariffs to allow for their successful implementation. The extent to which politicians are empowered to make these changes will vary on a jurisdictional basis.

Despite being responsible for catalysing a potential re-configuration of the electricity system, prosumers have limited avenues to interact with energy markets and/or assist in managing their impacts on electricity systems. Many new business models to integrate distributed energy resources (DER), including rooftop PV, into the electricity markets, such as via VPPs, P2P trading and demand response programs, have been proposed. However their implementation could require energy users to change their production, consumption and purchasing behaviours [78] and little is known about their willingness to do so [21,78].

The literature review undertaken by Freitas Gomes, Perez and Suomalainen [40] found that user acceptance was a key variable in determining whether people will invest in rooftop PV systems. Kang, Wei, Liu, Han, Yu and Wang [66] identified that more research is required to understand the roles played by individuals, businesses and communities in the energy transition. Ahl, Yarime, Tanaka and Sagawa [21] also reported that relationships between electricity users and blockchain-based P2P business models (and vice versa) have not been empirically studied.

Whilst transitioning current consumers into becoming prosumers makes sense in theory, actual behaviours may not conform to predictive models. Real-life trials have shown that those with solar PV's may use more energy during the day than prior to PV installation, and therefore there will be less PV-generated energy available for load shifting [38]. Behaviours may also vary for those with rooftop PV with batteries that are at home during the day versus those working away from home. The energy use behaviours of these households have the potential to influence the effectiveness of different policy responses, and therefore needs to be better understood. The S-SLR has shown that, to manage the transition to high rates of VRE, understanding the actual energy users, their 
acceptance of new technologies and enabling business models, together with users' actual responses to these, are all critical factors to be considered.

Another key theme emerging from the S-SLR was the need for an energy transition to address social justice issues $[36,83,106,107]$. This is because rooftop PV is more readily available to those users who own their own home. Energy consumers who rent or cannot afford to install rooftop PV are left to pay increasing energy prices, particularly as those installing rooftop solar start to add batteries and pay less towards the maintenance of the distribution infrastructure. This can result in a phenomenon referred to as the death spiral, where electricity supply prices rise as less energy is purchased from network providers, who have already invested in their infrastructure, whilst those remaining on the grid are left to pay for the grid infrastructure as the number of grid users diminish [79-82]. Some utilities are starting to promote restrictions on the number of rooftop PV systems that can be installed as a means to reduce social justice impacts [83]. Whereas some authors, such as Sareen and Kale [36], consider that addressing social justice issues must be considered in the early phases of transition planning by policy makers.

\subsection{Regulatory and Institutional Aspects}

The need for locally specific regulatory and policy support was identified in the SSLR [83]. The adoption of distributed energy resources and enabling markets can vary between neighbouring countries, demonstrating the importance of regulatory, policy and institutional factors in designing energy systems [78]. Policies that were consistently and longitudinally applied were found to be most effective in supporting VRE uptake $[65,108]$. Research shows that policy affects innovations and the innovations then affect policy settings in an iterative process [84].

Electricity provision has become a societal right in recent decades, which has renewed arguments on the role of markets versus governments in supplying this essential service $[7,15]$. As the list of services required to stabilise the electricity system grows with the uptake of rooftop PV, further policy research will be required to define the changing roles for governments, institutions and associated markets in electricity provision. This is particularly the case where new approaches are required to replicate services such as inertia, which was inherent to thermal generators but will be increasingly required throughout the transition. The role of government is further complicated in many systems, given that it often owns a significant portion of the existing generation and/or transmission and distribution system. Any policy changes allowing further development of renewable energy can negatively impact government assets and revenues, which can lead to inefficient decisions and further complicate the transition process.

Theo, et al. [109] noted that many regulatory and institutional barriers exist that preclude renewables from some market segments (such as providing ancillary services). As mentioned in Section 5.2, market rules in Western Australia were written to only allow generators to provide system support services, thereby excluding the use of batteries and other non-synchronous technologies [101,102]. This is despite energy storage being considered one of the most important mechanisms by which excess rooftop-PV-generated energy can best be integrated into existing power systems [110-112], in a state which has some of the highest daytime solar radiance in the world.

There are many factors that influence the speed at which enabling regulations and policy can keep pace with the uptake of VRE generally and rooftop PV specifically. Electricity systems in the developed world have been continually adjusting since at least the early 1900s to maintain reliable electricity supply as they have expanded to meet society's growing demand for electricity [25]. Society's relationship with electricity has also changed over this period from being a privilege, to an expected societal right [25]. The regulatory structures and technologies have co-evolved to promote reliability and stability, which has then reinforced a specific path-dependency. Whilst this has undoubtedly resulted in societal benefits through the provision of safe reliable electricity supplies, it has contributed to rigid regulative and normative practices that are ill equipped to respond to the current 
rapidly changing energy marketplace in Australia and elsewhere. In addition, as change is occurring at such a rapid pace, there is often insufficient appropriately skilled staff to resolve emergent issues [39].

\section{Conclusions: Integrating the MLP with the Four Aspects Uncovered in the SLR}

Electricity systems are changing with the installation of VRE sources. One form of VRE includes rooftop PV systems, which have unique impacts and require specific responses to manage their effects on the electricity system. The very high adoption rate of rooftop PV in some systems is forcing regulators, system operators, market participants, customers, technology providers, politicians and others associated with the electricity value chain to change their systems, practices and technologies at a pace that the electricity sector has not been exposed to since electricity was first introduced. To navigate the transition and maintain security of supply, policy makers must not limit their focus to the technical and /or economic parameters but must also consider the associated socio-political, policy and institutional changes that must be managed concurrently.

Theoretical frameworks can assist researchers to order and make sense of large amounts of multi-disciplinary information associated with an energy transition. Of the two long-range transitions theories reviewed in this paper, MLP and TEP, we consider the MLP to be more useful for policy makers with an interest in maintaining the security of electricity supply during a transition to high rates of rooftop PV. In this regard we support Schot and Kanger [64]'s criticism of the TEP for undervaluing the roles played by civil society, users, scientists, engineers, media and other social groups, whilst placing most attention on financial institutions and governments for creating the space for turning points to occur. This paper has identified many of the major technical, economic, socio-political and regulatory and institutional aspects that must be managed during a transition dominated by rooftop PV systems. The MLP of transition theory provides a useful framework in considering these multi-dimensional aspects.

Our research suggests that the transition frameworks must also be able to consider the rapid rates of change that are being dictated by the accelerating uptake of rooftop PV in some electricity systems. In systems where the transition is being led by rooftop PV adoptionit, is occurring at a smaller scale and faster pace than was possible with large electricity infrastructure associated with historical energy transitions. Whilst the MLP has been particularly effective in considering multi-decadal transitions, the accelerating rate of rooftop PV installations in some electricity systems may require a more time sensitive approach to framing these change processes. The impacts of rooftop PV on electricity systems will be, and is being, felt very soon in islanded networks with no interconnectors to neighbouring electricity systems. Research into managing the transition should therefore have a prioritised focus on islanded systems. Despite this, the literature reviewed in this paper uncovered very limited research into managing transition in islanded electricity systems with very high rates of rooftop PV uptake.

To assist policy makers in managing the transition, a deeper understanding of the technical and economic impacts of rooftop PV on wholesale energy markets and the associated physical electricity system will be required. Any policy changes made in response to these improved understandings will be constrained by lock-in mechanisms that have evolved as the incumbent energy systems have developed and should also be understood by those intending to manage a transition. This will include gaining a deep understanding of the political, social, regulatory and institutional aspects that can be leveraged to enable a transition or that need addressing so they do not block the successful change processes from occurring.

Whilst there has been significant research into the impacts of utility-scale renewable energy projects on established electricity systems, very little research has been carried out into systems where the transition is being driven by new supply from within the distribution network due to prosumer uptake of rooftop PV. Consequently, more research is required into the evolving roles of prosumers and how their participation can best be 
harnessed to assist in stabilising the newly developing electricity system. To do so could require an improved understanding of the evolving role of prosumers, both in their capacity to interact in energy markets, but also to facilitate change within the socio-technical regime through their support for niche technologies and markets that will be required to stabilise the effects of rooftop PV systems.

Author Contributions: Conceptualization, S.W. and M.J.; methodology, S.W. and G.M.M.; validation, S.W.; formal analysis, S.W.; data curation, S.W.; writing—original draft preparation, S.W.; writingreview and editing, S.W., M.J., and G.M.M.; visualization, S.W.; supervision, M.J. and G.M.M. All authors have read and agreed to the published version of the manuscript.

Funding: This research received no external funding.

Conflicts of Interest: The authors declare no conflict of interest. This research did not receive any specific grant from funding agencies in the public, commercial, or not-for-profit sectors. There are no conflicts of interest between the authors and this research. The views expressed are those of the authors and do not necessarily reflect those of an employer.

\section{Appendix A}

Table A1. Literature identified in the structured literature review component of the research and taken forward for further review. The table indicates whether each paper identified technical (Tech), economic (Econ), socio-political (Socio-Pol), and/or regulatory and institutional (Reg \& Inst) aspects within their research.

\begin{tabular}{lccc}
\hline \multicolumn{1}{c}{ Reference } & \multicolumn{2}{c}{ Aspects Considered } \\
\cline { 2 - 4 } & Tech & Econ & Socio-Pol \\
\hline Adil, A.M., Ko, Y., 2016. Socio-technical evolution of & & \\
$\begin{array}{l}\text { Decentralized Energy Systems: A critical review and } \\
\text { implications for urban planning and policy. Renewable and }\end{array}$ & 1 & 1 & 1 \\
Sustainable Energy Reviews 57, 1025-1037. & & & \\
\hline
\end{tabular}

Ahl, A., Yarime, M., Tanaka, K., Sagawa, D., 2019. Review of blockchain-based distributed energy: Implications for institutional development. Renewable and Sustainable Energy 1 1 1

Reviews 107, 200-211.

Al Arrouqi, R.A., Ellabban, O., Rasheed, M.B., Al-Fagih, L.,

2019. An Assessment of Different Electricity Tariffs on

Residential Photovoltaic System Profitability: Australian Case

Study. IEEE, pp. 1-6.

Alipour, M., Salim, H., Stewart, R.A., Sahin, O., 2020.

Predictors, taxonomy of predictors, and correlations of predictors with the decision behaviour of residential solar photovoltaics adoption: A review. Renewable and Sustainable Energy Reviews 123.

Ari, I., Koc, M., 2019. Sustainable Financing for Sustainable Development: Agent-Based Modeling of Alternative Financing Models for Clean Energy Investments. Sustainability 11.

Basit, M.A., Dilshad, S., Badar, R., Sami ur Rehman, S.M., 2020.

Limitations, challenges, and solution approaches in grid-connected renewable energy systems. International

Journal of Energy Research 44, 4132-4162.

Berg, A., Lukkarinen, J., Ollikka, K., 2020. 'Sticky' Policies-Three Country Cases on Long-Term Commitment and Rooting of RE Policy Goals. Energies 13.

Bhatt, B., Negi, A., 2018. Analysis of Rooftop Solar Photovoltaic System Across the Indian States: Learnings for Sustainable Infrastructure, Sustainable Development Research in the Asia-Pacific Region, pp. 393-419. 
Table A1. Cont.

\begin{tabular}{|c|c|c|c|c|}
\hline \multirow{2}{*}{ Reference } & \multicolumn{4}{|c|}{ Aspects Considered } \\
\hline & Tech & Econ & Socio-Pol & Reg \& Inst \\
\hline $\begin{array}{l}\text { Castellini, M., Menoncin, F., Moretto, M., Vergalli, S., } 2020 . \\
\text { Photovoltaic Smart Grids in the prosumers investment } \\
\text { decisions: a real option model. Journal of Economic Dynamics } \\
\text { and Control. }\end{array}$ & & 1 & 1 & \\
\hline
\end{tabular}

Fontenot, H., Dong, B., 2019. Modeling and control of building-integrated microgrids for optimal energy management - A review. Applied Energy 254.

Freitas Gomes, I.S., Perez, Y., Suomalainen, E., 2020. Coupling small batteries and PV generation: A review. Renewable and Sustainable Energy Reviews 126.

Gandhi, O., Kumar, D.S., Rodríguez-Gallegos, C.D.,

Srinivasan, D., 2020. Review of power system impacts at high

PV penetration Part I: Factors limiting PV penetration.

Solar Energy.

Gosens, J., Binz, C., Lema, R., 2020. China's role in the next phase of the energy transition: Contributions to global niche formation in the Concentrated Solar Power sector.

Environmental Innovation and Societal Transitions 34, 61-75.

Grøttum, H.H., Bjerland, S.F., Granado, P.C.d., Egging, R., 2019.

Modelling TSO-DSO coordination: The value of distributed

flexible resources to the power system. IEEE.

Ho, J.-Y., O'Sullivan, E., 2019. Addressing the evolving standardisation challenges of 'smart systems' innovation: Emerging roles for government? Science and Public Policy 46, 552-569.

Huang, P., 2019. The verticality of policy mixes for sustainability transitions: A case study of solar water heating in China. Research Policy 48.

Huang, P., Zhang, X., Copertaro, B., Saini, P.K., Yan, D., Wu, Y., Chen, X., 2020. A Technical Review of Modeling Techniques for Urban Solar Mobility: Solar to Buildings, Vehicles, and Storage (S2BVS). Sustainability 12.

Huuki, H., Karhinen, S., Böök, H., Lindfors, A.V., Kopsakangas-Savolainen, M., Svento, R., 2020. Utilizing the flexibility of distributed thermal storage in solar power 1

1
forecast error cost minimization. Journal of Energy Storage 28.

IEA PVPS, 2020. Snapshot of Global PV Markets 2020. Tech. Rep. T1-37:2020. International Energy Agency Photovoltaic Power Systems Programme (IEA PVPS).

Kabuth, A., Dahmke, A., Beyer, C., Bilke, L., Dethlefsen, F., Dietrich, P., Duttmann, R., Ebert, M., Feeser, V., Görke, U.-J.,

Köber, R., Rabbel, W., Schanz, T., Schäfer, D., Würdemann, H., Bauer, S., 2016. Energy storage in the geological subsurface: dimensioning, risk analysis and spatial planning: the ANGUS+ project. Environmental Earth Sciences 76.

Kang, J.-N., Wei, Y.-M., Liu, L.-C., Han, R., Yu, B.-Y., Wang, J.-W., 2020. Energy systems for climate change mitigation: A systematic review. Applied Energy 263. 
Table A1. Cont.

\begin{tabular}{|c|c|c|c|c|}
\hline \multirow{2}{*}{ Reference } & \multicolumn{4}{|c|}{ Aspects Considered } \\
\hline & Tech & Econ & Socio-Pol & Reg \& Inst \\
\hline $\begin{array}{l}\text { Katsanevakis, M., Stewart, R.A., Lu, J., 2017. Aggregated } \\
\text { applications and benefits of energy storage systems with } \\
\text { application-specific control methods: A review. Renewable } \\
\text { and Sustainable Energy Reviews 75, 719-741. }\end{array}$ & 1 & & & \\
\hline $\begin{array}{l}\text { Kelly, C., Onat, N.C., Tatari, O., 2019. Water and carbon } \\
\text { footprint reduction potential of renewable energy in the } \\
\text { United States: A policy analysis using system dynamics. } \\
\text { Journal of Cleaner Production } 228,910-926 .\end{array}$ & & 1 & & 1 \\
\hline $\begin{array}{l}\text { Khalilpour, R., Vassallo, A., 2016. Planning and operation } \\
\text { scheduling of PV-battery systems: A novel methodology. } \\
\text { Renewable and Sustainable Energy Reviews 53, 194-208. }\end{array}$ & 1 & 1 & & \\
\hline $\begin{array}{l}\text { Kourkoumpas, D.-S., Benekos, G., Nikolopoulos, N., Karellas, } \\
\text { S., Grammelis, P., Kakaras, E., 2018. A review of key } \\
\text { environmental and energy performance indicators for the case } \\
\text { of renewable energy systems when integrated with storage } \\
\text { solutions. Applied Energy 231, 380-398. }\end{array}$ & 1 & 1 & & \\
\hline $\begin{array}{l}\text { Lenhart, S., Chan, G., Forsberg, L., Grimley, M., Wilson, E., } \\
\text { 2020. Municipal utilities and electric cooperatives in the } \\
\text { United States: Interpretive frames, strategic actions, and } \\
\text { place-specific transitions. Environmental Innovation and } \\
\text { Societal Transitions 36, 17-33. }\end{array}$ & & & 1 & 1 \\
\hline
\end{tabular}

Lenhart, S., Nelson-Marsh, N., Wilson, E.J., Solan, D., 2016.

Electricity governance and the Western energy imbalance market in the United States: The necessity of

interorganizational collaboration. Energy Research \& Social

Science 19, 94-107.

Li, Q., Zhang, J., Chen, J., Lu, X., 2019. Reflection on opportunities for high penetration of renewable energy in China. Wiley Interdisciplinary Reviews: Energy and Environment 8.

Liu, J., Chen, X., Cao, S., Yang, H., 2019. Overview on hybrid solar photovoltaic-electrical energy storage technologies for power supply to buildings. Energy Conversion and Management 187, 103-121.

Marczinkowski, H.M., Østergaard, P.A., 2018. Residential versus communal combination of photovoltaic and battery in smart energy systems. Energy 152, 466-475.

McPherson, M., Johnson, N., Strubegger, M., 2018. The role of electricity storage and hydrogen technologies in enabling global low-carbon energy transitions. Applied Energy 216, 649-661.

Ninni, A., Lv, P., Spigarelli, F., Liu, P., 2020. How home and host country industrial policies affect investment location choice? The case of Chinese investments in the EU solar and wind industries. Journal of Industrial and Business Economics.

Nolting, L., Kies, A., Schönegge, M., Robinius, M., Praktiknjo, A., 2019. Locating experts and carving out the state of the art: A systematic review on Industry 4.0 and energy system analysis. International Journal of Energy Research 43, 
Table A1. Cont.

\begin{tabular}{|c|c|c|c|c|}
\hline \multirow{2}{*}{ Reference } & \multicolumn{4}{|c|}{ Aspects Considered } \\
\hline & Tech & Econ & Socio-Pol & Reg \& Inst \\
\hline $\begin{array}{l}\text { O'Shaughnessy, E., Cutler, D., Ardani, K., Margolis, R., } 2018 . \\
\text { Solar plus: A review of the end-user economics of solar PV } \\
\text { integration with storage and load control in residential } \\
\text { buildings. Applied Energy 228, 2165-2175. }\end{array}$ & 1 & 1 & 1 & \\
\hline $\begin{array}{l}\text { Palm, A., 2020. Early adopters and their motives: Differences } \\
\text { between earlier and later adopters of residential solar } \\
\text { photovoltaics. Renewable and Sustainable Energy } \\
\text { Reviews } 133 .\end{array}$ & & 1 & 1 & \\
\hline $\begin{array}{l}\text { Qazi, A., Hussain, F., Rahim, N.A.B.D., Hardaker, G., } \\
\text { Alghazzawi, D., Shaban, K., Haruna, K., 2019. Towards } \\
\text { Sustainable Energy: A Systematic Review of Renewable } \\
\text { Energy Sources, Technologies, and Public Opinions. IEEE } \\
\text { Access 7, 63837-63851. }\end{array}$ & & & 1 & \\
\hline $\begin{array}{l}\text { Rae, C., Kerr, S., Maroto-Valer, M.M., 2020. Upscaling smart } \\
\text { local energy systems: A review of technical barriers. } \\
\text { Renewable and Sustainable Energy Reviews } 131 .\end{array}$ & 1 & 1 & 1 & 1 \\
\hline $\begin{array}{l}\text { Rocha, R., Villar, J., Bessa, R.J., 2019. Business models for } \\
\text { Peer-to-Peer Energy Markets. IEEE. }\end{array}$ & 1 & 1 & & \\
\hline $\begin{array}{l}\text { Sackey, D.M., Owusu-Manu, D.-G., Asiedu, R.O., Jehuri, A.B., } \\
\text { 2020. Analysis of latent impeding factors to solar photovoltaic } \\
\text { investments in Ghana. International Journal of Energy Sector } \\
\text { Management 14, 669-682. }\end{array}$ & & 1 & 1 & \\
\hline $\begin{array}{l}\text { Sareen, S., Haarstad, H., 2018. Bridging socio-technical and } \\
\text { justice aspects of sustainable energy transitions. Applied } \\
\text { Energy 228, 624-632. }\end{array}$ & & & 1 & \\
\hline $\begin{array}{l}\text { Sareen, S., Kale, S.S., 2018. Solar 'power': Socio-political } \\
\text { dynamics of infrastructural development in two Western } \\
\text { Indian states. Energy Research \& Social Science 41, 270-278. }\end{array}$ & & 1 & 1 & \\
\hline $\begin{array}{l}\text { Selvakkumaran, S., Ahlgren, E.O., 2019. Determining the } \\
\text { factors of household energy transitions: A multi-domain study. } \\
\text { Technology in Society 57,54-75. }\end{array}$ & & 1 & & \\
\hline $\begin{array}{l}\text { Sinsel, S.R., Yan, X., Stephan, A., 2019. Building resilient } \\
\text { renewable power generation portfolios: The impact of } \\
\text { diversification on investors' risk and return. Applied } \\
\text { Energy } 254 .\end{array}$ & 1 & 1 & & \\
\hline $\begin{array}{l}\text { Solomon, A.A., Child, M., Caldera, U., Breyer, C., } 2020 . \\
\text { Exploiting wind-solar resource complementarity to reduce } \\
\text { energy storage need. AIMS Energy 8, 749-770. }\end{array}$ & 1 & & & \\
\hline $\begin{array}{l}\text { Steinhäuser, J.M., Eisenack, K., 2020. How market design } \\
\text { shapes the spatial distribution of power plant curtailment } \\
\text { costs. Energy Policy } 144 .\end{array}$ & & 1 & & \\
\hline $\begin{array}{l}\text { Theo, W.L., Lim, J.S., Ho, W.S., Hashim, H., Lee, C.T., } 2017 . \\
\text { Review of distributed generation (DG) system planning and } \\
\text { optimisation techniques: Comparison of numerical and } \\
\text { mathematical modelling methods. Renewable and Sustainable } \\
\text { Energy Reviews 67, 531-573. }\end{array}$ & 1 & 1 & 1 & 1 \\
\hline $\begin{array}{l}\text { Thombs, R.P., 2019. When democracy meets energy transitions: } \\
\text { A typology of social power and energy system scale. Energy } \\
\text { Research \& Social Science } 52,159-168 \text {. }\end{array}$ & & & 1 & \\
\hline
\end{tabular}


Table A1. Cont.

\begin{tabular}{|c|c|c|c|c|}
\hline \multirow{2}{*}{ Reference } & \multicolumn{4}{|c|}{ Aspects Considered } \\
\hline & Tech & Econ & Socio-Pol & Reg \& Inst \\
\hline $\begin{array}{l}\text { Trotter, P.A., Maconachie, R., McManus, M.C., 2018. Solar } \\
\text { energy's potential to mitigate political risks: The case of an } \\
\text { optimised Africa-wide network. Energy Policy 117, 108-126. }\end{array}$ & & & 1 & \\
\hline $\begin{array}{l}\text { Urpelainen, J., Yoon, S., 2017. Can product demonstrations } \\
\text { create markets for sustainable energy technology? A } \\
\text { randomized controlled trial in rural India. Energy Policy 109, } \\
666-675 .\end{array}$ & 1 & 1 & & \\
\hline $\begin{array}{l}\text { van Summeren, L.F.M., Wieczorek, A.J., Bombaerts, G.J.T., } \\
\text { Verbong, G.P.J., 2020. Community energy meets smart grids: } \\
\text { Reviewing goals, structure, and roles in Virtual Power Plants } \\
\text { in Ireland, Belgium and the Netherlands. Energy Research \& } \\
\text { Social Science } 63 .\end{array}$ & 1 & & 1 & 1 \\
\hline $\begin{array}{l}\text { von Wirth, T., Gislason, L., Seidl, R., 2018. Distributed energy } \\
\text { systems on a neighborhood scale: Reviewing drivers of and } \\
\text { barriers to social acceptance. Renewable and Sustainable } \\
\text { Energy Reviews 82, 2618-2628. }\end{array}$ & & 1 & 1 & 1 \\
\hline $\begin{array}{l}\text { Wolsink, M., 2019. Social acceptance, lost objects, and } \\
\text { obsession with the 'public'-The pressing need for enhanced } \\
\text { conceptual and methodological rigor. Energy Research \& } \\
\text { Social Science } 48,269-276 .\end{array}$ & & & 1 & \\
\hline Totals & 30 & 31 & 25 & 16 \\
\hline
\end{tabular}

\section{References}

1. Blakers, A.; Stocks, M.; Lu, B.; Cheng, C. Australia's Rapid Renewable Energy Transition. In Proceedings of the ISES Solar World Congress 2019, Santiago, Chile, 4-7 November 2019; pp. 1-4.

2. Energy Transformation Taskforce. Distributed Energy Resources Roadmap 2020. Available online: https:/ / brighterenergyfuture. wa.gov.au/wp-content/uploads/2020/04/DER-Roadmap_April2020.pdf (accessed on 8 January 2020).

3. Australian PV Institute. Percentage of Dwellings with a PV System by State/Territory. Available online: https://pv-map.apvi. org.au/historical (accessed on 8 December 2020).

4. Gerres, T.; Ávila, J.P.C.; Martínez, F.M.; Abbad, M.R.; Arín, R.C.; Miralles, Á.S. Rethinking the electricity market design: Remuneration mechanisms to reach high RES shares. Results from a Spanish case study. Energy Policy 2019, 129, 1320-1330. [CrossRef]

5. Hirth, L. The market value of variable renewables. Energy Econ. 2013, 38, 218-236. [CrossRef]

6. Woo, C.K.; Zarnikau, J. A nice electricity market design. Electr. J. 2019, 32. [CrossRef]

7. Liebreich, M. Six Design Principles for the Power Markets of the Future. In Bloomberg New Energy Finance; Bloomberg: London, UK, 2017.

8. Hess, D.J.; Lee, D. Energy decentralization in California and New York: Conflicts in the politics of shared solar and community choice. Renew. Sustain. Energy Rev. 2020, 121, 109716. [CrossRef]

9. Gandhi, O.; Kumar, D.S.; Rodríguez-Gallegos, C.D.; Srinivasan, D. Review of power system impacts at high PV penetration Part I: Factors limiting PV penetration. Sol. Energy 2020, 210, 181-201. [CrossRef]

10. Castellini, M.; Menoncin, F.; Moretto, M.; Vergalli, S. Photovoltaic Smart Grids in the prosumers investment decisions: A real option model. J. Econ. Dyn. Control 2020. [CrossRef]

11. Boscán, L.; Poudineh, R. Business Models for Power System Flexibility: New Actors, New Roles, New Rules. In Future of Utilities Utilities of the Future; Elsevier: Amsterdam, The Netherlands, 2016.

12. Van Summeren, L.F.M.; Wieczorek, A.J.; Bombaerts, G.J.T.; Verbong, G.P.J. Community energy meets smart grids: Reviewing goals, structure, and roles in Virtual Power Plants in Ireland, Belgium and the Netherlands. Energy Res. Soc. Sci. $2020,63$. [CrossRef]

13. Woodhouse, S. Decentralized Reliability Options: Market Based Capacity Arrangements. In Future of Utilities Utilities of the Future; Elsevier: Amsterdam, The Netherlands, 2016.

14. Joachim, S.; Andrew, D.M.; Ryan, H.W. Impacts of High Variable Renewable Energy Futures on Wholesale Electricity Prices, and on Electric-Sector Decision Making; Berkeley Lab: Berkeley, CA, USA, 2018.

15. Abbott, M.; Cohen, B. Maintaining the security of supply in the Australian national electricity Market with higher levels of renewable energy. Electr. J. 2019, 32, 9. [CrossRef] 
16. Sioshansi, F.P. California's 'Duck Curve' Arrives Well Ahead of Schedule. Electr. J. 2016, 29, 71-72.

17. Janko, S.A.; Arnold, M.R.; Johnson, N.G. Implications of high-penetration renewables for ratepayers and utilities in the residential solar photovoltaic (PV) market. Appl. Energy 2016, 180, 37-51. [CrossRef]

18. Boßmann, T.; Staffell, I. The shape of future electricity demand: Exploring load curves in 2050s Germany and Britain. Energy 2015, 90, 1317-1333. [CrossRef]

19. Australian Energy Market Operator (AEMO). Integrating Utility-Scale Renewables and Distributed Energy Resources in the SWIS; Australian Energy Market Operator: Melbourne, Australia, 2019.

20. Australian Energy Market Operator (AEMO). Technical Integration of Distributed Energy Resources: Improving DER Capabilities to Benefit Consumers and the Power System; Australian Energy Market Operator: Melbourne, Australia, 2019.

21. Ahl, A.; Yarime, M.; Tanaka, K.; Sagawa, D. Review of blockchain-based distributed energy: Implications for institutional development. Renew. Sustain. Energy Rev. 2019, 107, 200-211. [CrossRef]

22. Hirsch, A.; Parag, Y.; Guerrero, J. Microgrids: A review of technologies, key drivers, and outstanding issues. Renew. Sustain. Energy Rev. 2018, 90, 402-411. [CrossRef]

23. Von Wirth, T.; Gislason, L.; Seidl, R. Distributed energy systems on a neighborhood scale: Reviewing drivers of and barriers to social acceptance. Renew. Sustain. Energy Rev. 2018, 82, 2618-2628. [CrossRef]

24. Wüstenhagen, R.; Wolsink, M.; Bürer, M.J. Social acceptance of renewable energy innovation: An introduction to the concept. Energy Policy 2007, 35, 2683-2691. [CrossRef]

25. Bakke, G. The Grid: The Fraying Wires Between Americans and Our Energy Future; Bloomsbury: New York, NY, USA, $2016 ;$ p. 351.

26. Grøttum, H.H.; Bjerland, S.F.; Granado, P.C.; Egging, R. Modelling TSO-DSO coordination: The value of distributed flexible resources to the power system. In Proceedings of the 2019 16th International Conference on the European Energy Market (EEM), Ljubljana, Slovenia, 18-20 September 2019.

27. Strambach, S.; Pflitsch, G. Transition topology: Capturing institutional dynamics in regional development paths to sustainability. Res. Policy 2020, 49, 7. [CrossRef]

28. Köhler, J.; Geels, F.W.; Kern, F.; Markard, J.; Onsongo, E.; Wieczorek, A.; Alkemade, F.; Avelino, F.; Bergek, A.; Boons, F.; et al. An agenda for sustainability transitions research: State of the art and future directions. Environ. Innov. Soc. Transit. 2019, 31, 1-32. [CrossRef]

29. Geels, F.W.; Berkhout, F.; van Vuuren, D.P. Bridging analytical approaches for low-carbon transitions. Nat. Clim. Chang. 2016, 6, 576-583. [CrossRef]

30. Li, F.G.N.; Trutnevyte, E.; Strachan, N. A review of socio-technical energy transition (STET) models. Technol. Forecast. Soc. Chang. 2015, 100, 290-305. [CrossRef]

31. Strauss, A.; Corbin, J. Basics of Qualitative Research: Techniques and Procedures for Developing Grounded Theory, 2nd ed.; Sage Publications: Thousand Oaks, CA, USA, 1998.

32. Snyder, H. Literature review as a research methodology: An overview and guidelines. J. Bus. Res. 2019, 104, 333-339. [CrossRef]

33. Davis, J.; Mengersen, K.; Bennett, S.; Mazerolle, L. Viewing systematic reviews and meta-analysis in social research through different lenses. SpringerPlus 2014, 3, 511. [CrossRef] [PubMed]

34. Sovacool, B.K.; Axsen, J.; Sorrell, S. Promoting novelty, rigor, and style in energy social science: Towards codes of practice for appropriate methods and research design. Energy Res. Soc. Sci. 2018, 45, 12-42. [CrossRef]

35. Lagisz, M.; Samarasinghe, G.; Nakagawa, S. Rapid Reviews for the Built Environment-Methodology and Guidelines; CRCLCL: Sydney, Australia, 2018.

36. Sareen, S.; Kale, S.S. Solar 'power': Socio-political dynamics of infrastructural development in two Western Indian states. Energy Res. Soc. Sci. 2018, 41, 270-278. [CrossRef]

37. Alipour, M.; Salim, H.; Stewart, R.A.; Sahin, O. Predictors, taxonomy of predictors, and correlations of predictors with the decision behaviour of residential solar photovoltaics adoption: A review. Renew. Sustain. Energy Rev. 2020, 123, 109749. [CrossRef]

38. O'Shaughnessy, E.; Cutler, D.; Ardani, K.; Margolis, R. Solar plus: A review of the end-user economics of solar PV integration with storage and load control in residential buildings. Appl. Energy 2018, 228, 2165-2175. [CrossRef]

39. Bhatt, B.; Negi, A. Analysis of Rooftop Solar Photovoltaic System Across the Indian States: Learnings for Sustainable Infrastructure. In Sustainable Development Research in the Asia-Pacific Region; Springer: Berlin/Heidelberg, Germany, 2018; pp. $393-419$.

40. Gomes, I.S.F.; Perez, Y.; Suomalainen, E. Coupling small batteries and PV generation: A review. Renew. Sustain. Energy Rev. 2020, 126. [CrossRef]

41. Adil, A.M.; Ko, Y. Socio-technical evolution of Decentralized Energy Systems: A critical review and implications for urban planning and policy. Renew. Sustain. Energy Rev. 2016, 57, 1025-1037. [CrossRef]

42. Gottschamer, L.; Zhang, Q. Interactions of factors impacting implementation and sustainability of renewable energy sourced electricity. Renew. Sustain. Energy Rev. 2016, 65, 164-174. [CrossRef]

43. Sovacool, B.K.; Hess, D.J.; Amir, S.; Geels, F.W.; Hirsh, R.; Medina, L.R.; Miller, C.; Palavicino, C.A.; Phadke, R.; Ryghaug, M.; et al. Sociotechnical agendas: Reviewing future directions for energy and climate research. Energy Res. Soc. Sci. 2020, 70. [CrossRef]

44. Sovacool, B.K.; Hess, D.J. Ordering theories: Typologies and conceptual frameworks for sociotechnical change. Soc. Stud. Sci. 2017, 47, 703-750. [CrossRef]

45. Mathews, J.A. The renewable energies technology surge: A new techno-economic paradigm in the making? Futures 2013, 46, 10-22. [CrossRef] 
46. Perez, C. Technological revolutions and techno-economic paradigms. Camb. J. Econ. 2009, 34, 185-202. [CrossRef]

47. Freeman, C.; Perez, C. Structural crises of adjustment: Business cycles and investment behaviour. In Technical Change and Economic Theory; Pinter Publishers: London, UK, 1988.

48. Geels, F.W. From sectoral systems of innovation to socio-technical systems. Res. Policy 2004, 33, 897-920. [CrossRef]

49. Geels, F. Technological transitions as evolutionary reconfiguration processes: A multi-level perspective and a case-study. Res. Policy 2002, 31, 1257-1274. [CrossRef]

50. Geels, F.W.; Schot, J. Typology of sociotechnical transition pathways. Res. Policy 2007, 36, 399-417. [CrossRef]

51. Smith, A.; Voß, J.-P.; Grin, J. Innovation studies and sustainability transitions: The allure of the multi-level perspective and its challenges. Res. Policy 2010, 39, 435-448. [CrossRef]

52. Geels, F.W. The multi-level perspective on sustainability transitions: Responses to seven criticisms. Environ. Innov. Soc. Transit. 2011, 1, 24-40. [CrossRef]

53. Verbong, G.; Geels, F. Exploring sustainability transitions in the electricity sector with socio-technical pathways. Technol. Forecast. Soc. Chang. 2010, 77, 1214-1221. [CrossRef]

54. Unruh, G.C. Escaping carbon lock-in. Energy Policy 2002, 30, 317-325. [CrossRef]

55. Köhler, J.; Geels, F.; Kern, F.; Onsongo, E.; Wieczorek, A. A Research Agenda for the Sustainability Transitions Research Network; Sustainability Transitions Research Network: 2017. Available online: https://transitionsnetwork.org/wp-content/uploads/2018 /01/STRN_Research_Agenda_2017.pdf (accessed on 27 April 2019).

56. Booth, R.R.; Coulter, T.E. A Review of Rural Electrification Policies in Western Australia; Institution of Engineers: Sydney, Australia, 1980; pp. 178-182.

57. Schot, J.; Kanger, L.; Verbong, G.G. The roles of users in shaping transitions to new energy systems. Nat. Energy 2016, 1, 16054. [CrossRef]

58. Wilkinson, S.; Hojckova, K.; Eon, C.; Morrison, G.M.; Sandén, B. Is peer-to-peer electricity trading empowering users? Evidence on motivations and roles in a prosumer business model trial in Australia. Energy Res. Soc. Sci. 2020, 66, 101500. [CrossRef]

59. Hansen, T.; Coenen, L. The geography of sustainability transitions: Review, synthesis and reflections on an emergent research field. Environ. Innov. Soc. Transit. 2015, 17, 92-109. [CrossRef]

60. Wells, P.; Lin, X. Spontaneous emergence versus technology management in sustainable mobility transitions: Electric bicycles in China. Transp. Res. Part A Policy Pract. 2015, 78, 371-383. [CrossRef]

61. Coenen, L.; Benneworth, P.; Truffer, B. Toward a spatial perspective on sustainability transitions. Res. Policy 2012, 41, 968-979. [CrossRef]

62. Chandrashekeran, S. Multidimensionality and the multilevel perspective: Territory, scale, and networks in a failed demand-side energy transition in Australia. Environ. Plan. A Econ. Space 2016, 48, 1636-1656. [CrossRef]

63. Zolfagharian, M.; Walrave, B.; Raven, R.; Romme, A.G.L. Studying transitions: Past, present, and future. Res. Policy 2019, 48, 103788. [CrossRef]

64. Schot, J.; Kanger, L. Deep Transitions: Emergence, Acceleration, Stabilization and Directionality. SSRN Electron. J. 2016, 47, 1045-1059. [CrossRef]

65. Gosens, J.; Binz, C.; Lema, R. China's role in the next phase of the energy transition: Contributions to global niche formation in the Concentrated Solar Power sector. Environ. Innov. Soc. Transit. 2020, 34, 61-75. [CrossRef]

66. Kang, J.-N.; Wei, Y.-M.; Liu, L.-C.; Han, R.; Yu, B.-Y.; Wang, J.-W. Energy systems for climate change mitigation: A systematic review. Appl. Energy 2020, 263, 114602. [CrossRef]

67. Wolsink, M. Social acceptance, lost objects, and obsession with the 'public'-The pressing need for enhanced conceptual and methodological rigor. Energy Res. Soc. Sci. 2019, 48, 269-276. [CrossRef]

68. Austin, D. Future Grid Stability Needs Remote Control Renewables. Available online: https://reneweconomy.com.au/futuregrid-stability-needs-remote-control-renewables-54360/ (accessed on 12 March 2020).

69. Riesz, J.; Macgill, I. Frequency Control Ancillary Services: Is Australia a Model Market for Renewable Integration? In Proceedings of the 12th International Workshop on Large-Scale Integration of Wind Power into Power Systems, London, UK, 22-24 October 2013.

70. Australian Energy Market Operator (AEMO). System Strength Requirements Methodology: System Strength Requirements E Fault Level Shortfalls; Australian Energy Market Operator: Melbourne, Australia, 2018.

71. Lagarde, C.M.D.; Lantz, F. How renewable production depresses electricity prices: Evidence from the German market. Energy Policy 2018, 117, 263-277. [CrossRef]

72. Tveten, Å.G.; Bolkesjø, T.F.; Martinsen, T.; Hvarnes, H. Solar feed-in tariffs and the merit order effect: A study of the German electricity market. Energy Policy 2013, 61, 761-770. [CrossRef]

73. Woo, C.; Moore, J.; Schneiderman, B.; Ho, T.; Olson, A.; Alagappan, L.; Chawla, K.; Toyama, N.; Zarnikau, J. Merit-order effects of renewable energy and price divergence in California's day-ahead and real-time electricity markets. Energy Policy 2016, 92, 299-312. [CrossRef]

74. International Energy Agency. Re-Powering Markets; International Energy Agency: Paris, France, 2016.

75. Bertolini, M.; D'Alpaos, C.; Moretto, M. Do Smart Grids boost investments in domestic PV plants? Evidence from the Italian electricity market. Energy 2018, 149, 890-902. [CrossRef] 
76. International Energy Agency. The Power of Transformation: Wind, Sun and the Economics of Flexible Power Systems; International Energy Agency: Paris, France, 2014.

77. Rae, C.; Kerr, S.; Maroto-Valer, M.M. Upscaling smart local energy systems: A review of technical barriers. Renew. Sustain. Energy Rev. 2020, 131, 110020. [CrossRef]

78. Athawale, R.; Felder, F. Residential Rate Design and Death Spiral for Electric Utilities: Efficiency and Equity Considerations. In Future of Utilities Utilities of the Future; Elsevier: Amsterdam, The Netherlands, 2016; pp. 193-209.

79. Castaneda, M.; Jimenez, M.; Zapata, S.; Franco, C.J.; Dyner, I. Myths and facts of the utility death spiral. Energy Policy 2017, 110, 105-116. [CrossRef]

80. Grace, B. Beyond the Death Spiral: Transitioning to Renewable Energy in Western Australia; Sustainable Energy Now: Perth, Australia, 2017.

81. Laws, N.D.; Epps, B.P.; Peterson, S.O.; Laser, M.S.; Wanjiru, G.K. On the utility death spiral and the impact of utility rate structures on the adoption of residential solar photovoltaics and energy storage. Appl. Energy 2017, 185, 627-641. [CrossRef]

82. Lenhart, S.; Chan, G.; Forsberg, L.; Grimley, M.; Wilson, E. Municipal utilities and electric cooperatives in the United States: Interpretive frames, strategic actions, and place-specific transitions. Environ. Innov. Soc. Transit. 2020, 36, 17-33. [CrossRef]

83. Huang, P. The verticality of policy mixes for sustainability transitions: A case study of solar water heating in China. Res. Policy 2019, 48, 103758. [CrossRef]

84. Turnheim, B.; Geels, F.W. The destabilisation of existing regimes: Confronting a multi-dimensional framework with a case study of the British coal industry (1913-1967). Res. Policy 2013, 42, 1749-1767. [CrossRef]

85. Australian Energy Market Operator (AEMO). Costs and Technical Parameter Review; Australian Energy Market Operator: Melbourne, Australia, 2018.

86. Australian Energy Market Operator (AEMO). Wholesale Electricity Market Electricity Statement of Opportunities; Australian Energy Market Operator: Melbourne, Australia, 2020.

87. Australian Energy Market Operator (AEMO). Generation Mix Dataset; Australian Energy Market Operator: Melbourne, Australia, 2020.

88. Gürtler, M.; Paulsen, T. The effect of wind and solar power forecasts on day-ahead and intraday electricity prices in Germany. Energy Econ. 2018, 75, 150-162. [CrossRef]

89. Yazdani, A.; Zarghami, M.; Vaziri, M.; Tatro, R.; Vadhva, S.; Macari, E. Distributed Generation Impacts, Cyber Security Issue Identification, and Home Area Network Design; California Energy Agency: Sacramento, CA, USA, 2017.

90. Tayal, D. Achieving high renewable energy penetration in Western Australia using data digitisation and machine learning. Renew. Sustain. Energy Rev. 2017, 80, 1537-1543. [CrossRef]

91. National Renewable Energy Laboratory. Renewable Electricity Futures Study—Volume 2 of 4: Renewable Electricity Generation and Storage Technologies. Available online: https://www.nrel.gov/docs/fy12osti/52409-2.pdf (accessed on 8 December 2020).

92. Giraldez, J.A.; Hoke, P.; Gotseff, N.; Wunder, M.; Blonsky, M.; Emmanuel, A.; Latif, E.; Ifuku, M.; Asano, T.; Aukai, A.; et al. Advanced Inverter Voltage Controls: Simulation and Field Pilot Findings. Available online: https://www.nrel.gov/docs/fy1 9osti/72298.pdf (accessed on 8 December 2020).

93. Sperstad, I.B.; Degefa, M.Z.; Kjølle, G. The impact of flexible resources in distribution systems on the security of electricity supply: A literature review. Electr. Power Syst. Res. 2020, 188, 106532. [CrossRef]

94. Parag, Y.; Sovacool, B.K. Electricity market design for the prosumer era. Nat. Energy 2016, 1, 16032. [CrossRef]

95. Rodríguez-Molina, J.; Martínez-Núñez, M.; Martínez, J.-F.; Pérez-Aguiar, W. Business Models in the Smart Grid: Challenges, Opportunities and Proposals for Prosumer Profitability. Energies 2014, 7, 6142-6171. [CrossRef]

96. International Renewable Energy Agency (IRENA). Global Renewables Outlook: Energy Transformation 2050; International Renewable Energy Agency: Abu Dhabi, United Arab Emirates, 2020.

97. Battery Pack Prices Fall as Market Ramps Up with Market Average At $\$ 156 / \mathrm{kWh}$ in 2019. In Bloomberg New Energy Finance; Bloomberg: London, UK, 2019.

98. International Renewable Energy Agency (IRENA). Renewable Power Generation Costs in 2019; IRENA: Abu Dhabi, United Arab Emirates, 2019.

99. International Energy Agency. World Energy Outlook: Executive Summary; International Energy Agency: Paris, France, 2020.

100. Maticka, M.J. The SWIS DUCK-Value pricing analysis of commercial scale photovoltaic generation in the South West Interconnected System. Electr. J. 2019, 32, 57-65. [CrossRef]

101. Independent Market Operator. Wholesale Electricity Market Design Summary; Independent Market Operator: Melbourne, Australia, 2012.

102. Government of Western Australia. Wholesale Electricity Market Rules; Government of Western Australia: Sydney, Australia, 2015.

103. Satchwell, A.; Mills, A.; Barbose, G. Regulatory and ratemaking approaches to mitigate financial impacts of net-metered PV on utilities and ratepayers. Energy Policy 2015, 85, 115-125. [CrossRef]

104. Tayal, D.; Evers, U. Consumer preferences and electricity pricing reform in Western Australia. Util. Policy 2018, 54, 115-124. [CrossRef]

105. Trotter, P.A.; Maconachie, R.; McManus, M.C. Solar energy's potential to mitigate political risks: The case of an optimised Africa-wide network. Energy Policy 2018, 117, 108-126. [CrossRef]

106. Thombs, R.P. When democracy meets energy transitions: A typology of social power and energy system scale. Energy Res. Soc. Sci. 2019, 52, 159-168. [CrossRef]

107. Sareen, S.; Haarstad, H. Bridging socio-technical and justice aspects of sustainable energy transitions. Appl. Energy 2018, 228, 624-632. [CrossRef] 
108. Berg, A.; Lukkarinen, J.; Ollikka, K. 'Sticky' Policies-Three Country Cases on Long-Term Commitment and Rooting of RE Policy Goals. Energies 2020, 13, 1351. [CrossRef]

109. Theo, W.L.; Lim, J.S.; Ho, W.S.; Hashim, H.; Lee, C.T. Review of distributed generation (DG) system planning and optimisation techniques: Comparison of numerical and mathematical modelling methods. Renew. Sustain. Energy Rev. 2017, 67, 531-573. [CrossRef]

110. Das, C.K.; Bass, O.; Mahmoud, T.S.; Kothapalli, G.; Masoum, M.A.; Mousavi, N. An optimal allocation and sizing strategy of distributed energy storage systems to improve performance of distribution networks. J. Energy Storage 2019, $26,100847$. [CrossRef]

111. Das, C.K.; Bass, O.; Kothapalli, G.; Mahmoud, T.S.; Habibi, D. Overview of energy storage systems in distribution networks: Placement, sizing, operation, and power quality. Renew. Sustain. Energy Rev. 2018, 91, 1205-1230. [CrossRef]

112. Katsanevakis, M.; Stewart, R.A.; Lu, J. Aggregated applications and benefits of energy storage systems with application-specific control methods: A review. Renew. Sustain. Energy Rev. 2017, 75, 719-741. [CrossRef] 